\title{
A Study on Contact Fatigue Performance of Nitrided and TiN Coated Gears
}

\author{
Hongbin $\mathrm{Xu},{ }^{1} \mathrm{Hui} \mathrm{Li}^{2}{ }^{2}$ Jianjun $\mathrm{Hu}^{2}{ }^{2}$ and Song Wang ${ }^{2}$ \\ ${ }^{1}$ Key Laboratory of Manufacture and Test Techniques for Automobile Parts, Ministry of Education, Chongqing 400054, China \\ ${ }^{2}$ Material Science and Engineering College, Chongqing University of Technology, Chongqing 400054, China
}

Correspondence should be addressed to Hui Li; 28406053@qq.com

Received 19 July 2013; Accepted 1 September 2013

Academic Editor: Xing Chen

Copyright (C) 2013 Hongbin Xu et al. This is an open access article distributed under the Creative Commons Attribution License, which permits unrestricted use, distribution, and reproduction in any medium, provided the original work is properly cited.

This paper discusses the effects of TiN coating on gear contact fatigue performance through contact fatigue experiment and gear rig test. The results reveal that the deposition on gears with hard coating TiN could provide the subsurface protection and improve the contact fatigue life, and the contact fatigue strength of nitrided+TiN coated $32 \mathrm{Cr} 2 \mathrm{MoV}$ is $1557 \mathrm{MPa}$ at survival probability of $99 \%, 284 \mathrm{MPa}$ higher than that of nitrided $32 \mathrm{Cr} 2 \mathrm{MoV}$. Although TiN coating on the the edge of the meshing zone wore out, there is no obvious pitting at the site and the rest of meshed zone of TiN coated gear keeps well without pittings and wear grooves, which is opposite to nitrided gears with pittings and peeling off. TiN coating is dense and smooth with lower surface roughness, and it wraps up the gear tooth so that the gear surface no longer contacts with lubricant and prevents the cracks initiation, prolonging the contact fatigue life of gears.

\section{Introduction}

The development in trend of gears, focusing on high-speed, heavy-duty, light weight, and small sizes, makes hardness promotion of gear face through traditional surface treatment and improvement of the bearing capacity of gears by enlarging module faces many limitations. Special work conditions require new type of surface strengthening methods as well as new gear materials with high performance. The hard thin coatings with lower friction and higher wear-resistance, for instance, $\mathrm{MoS}_{2}$ [1], DLC [2], WC/C [3, 4], TiN [5, 6], or the others $[5,7]$, have been studied for enhancing the surface contact fatigue life. In most cases, the effects of hard coatings on rolling contact fatigue have been mainly investigated by using a roller tester, pin-on-ring tester, three ball-on-rod tester, and so on, which reveals that coatings deposited by PVD could improve the wear resistance and contact fatigue life of substrate. However, it is not always easy to evaluate the tribological properties of tooth surface in meshingly using these fundamental testers $[8,9]$.

Among the common ceramic coatings, the titanium nitride (TiN) is featured by excellent wear-resistance, low friction against metals, and more mature technology, making it widely used in tool and die industry [10, 11]. To confirm the effects of surface engineering on load carrying capacity of gears, this paper dwelled on load carrying capacity of nitrided and TiN deposited gears by means of contact fatigue experiment and gear rig test; additional tooth surface failure was investigated.

\section{Experiment Details}

According to Chinese Standard, $32 \mathrm{Cr} 2 \mathrm{MoV}$ whose composition was reported in Table 1 was selected to proceed with the experiment, and the geometrical characteristic of gears used in test was presented in Table 2. Heat treatments of samples were as follows: (1) austenitizing at $940^{\circ} \mathrm{C}$ for $1 \mathrm{~h},(2)$ oil cooling to room temperature, and (3) heating up to $640^{\circ} \mathrm{C}$ and holding for $1.5 \mathrm{~h}$, then air cooling. After tempering and machining, all samples have been plasma nitrided at $530^{\circ} \mathrm{C} \sim$ $550^{\circ} \mathrm{C}$ for 20 hours.

To synthesize the TiN coating by multi-arc ion plating, the work chamber was first vacuumed to pressure of $6.67 \times$ $10^{-4} \mathrm{~Pa}$, and then Ar gas was introduced into the chamber to clean the workpiece surface by sputtering for 5 minutes. 
TABLE 1: The composition of 32Cr2MoV (Wt/\%).

\begin{tabular}{lcccccc}
\hline Material & $\mathrm{C}$ & $\mathrm{Si}$ & $\mathrm{Mn}$ & $\mathrm{Cr}$ & $\mathrm{Mo}$ & $\mathrm{V}$ \\
\hline $32 \mathrm{Cr} 2 \mathrm{MoV}$ & $0.30 \sim 0.34$ & $0.34 \sim 0.38$ & $0.48 \sim 0.60$ & $2.10 \sim 2.23$ & $1.3 \sim 1.6$ & 0.24 \\
\hline
\end{tabular}

TABLE 2: Gear specification.

\begin{tabular}{lcccccc}
\hline Gear type & Tooth profile & Accuracy & Module $/ \mathrm{mm}$ & Number of teeth & Pressure angle & Surface hardness \\
\hline Drive gears & \multirow{2}{*}{ Standard involutes } & 5 & 1.75 & 17 & $20^{\circ}$ & $>$ HRC 58 \\
Driven gears & & 5 & 1.75 & 32 & $>$ HRC 58 \\
\hline
\end{tabular}

TABLE 3: Operating conditions in gear test.

\begin{tabular}{lcccc}
\hline $\begin{array}{l}\text { Torque } \\
T / \mathrm{N} \cdot \mathrm{m}\end{array}$ & $\begin{array}{c}\text { Rotational } \\
\text { speed R } \\
\mathrm{r} / \mathrm{min}\end{array}$ & $\begin{array}{c}\text { Normal } \\
\text { load L/N }\end{array}$ & $\begin{array}{c}\text { Contact } \\
\text { stress } \\
\sigma / \mathrm{MPa}\end{array}$ & Time $t / \mathrm{h}$ \\
\hline 16.71 & 2000 & 1250 & 1235 & 84 \\
\hline
\end{tabular}

A DC bias voltage $200 \mathrm{~V}$ was applied on the Ti target to motivate the ionic Ti coated on the surface for 3 minutes. Then, $\mathrm{N}_{2}$ of $4.0 \times 10^{-1} \mathrm{~Pa}$ work pressure was introduced into the chamber to deposit the TiN film onto the nitrided substrate.

Technical specification of samples and fatigue experiment procedure followed the experiment method of metal line contact rolling fatigue (Chinese National Standard GB10622-89). The fatigue experiment conditions were as follows: the four stress levels were $2500 \mathrm{MPa}, 2200 \mathrm{MPa}, 2000 \mathrm{MPa}$, and $1800 \mathrm{MPa}$, slip ratio was $10 \%$, the rotational speed of drive samples was $1400 \mathrm{r} / \mathrm{min}$, temperature of lubricant kept $<40^{\circ} \mathrm{C}$. The five valid samples were chosen at every stress level to achieve the accurate numbers of cycles.

After the contact fatigue strength was obtained by contact fatigue experiment, the load carrying capacity of TiN coated gears has been analyzed by means of gear rig contact test; the conditions were as shown in Table 3.

The failure surface of gears was firstly examined by stereomicroscope and microscope, in particular the fracture surfaces prior to being observed by scanning electron microscopy (SEM). Also, the surface roughness of gears was measured.

\section{Results and Discussion}

The numbers of cycles in different contact stress levels for the nitrided and nitrided+TiN coated samples were presented in Table 4, which illustrated that the numbers of cycles of nitrided+TiN coated samples were larger than those of nitrided samples under the same failure criterion and experimental condition.

By analyzing numbers of cycles with Fixed Emitting Point Method-An Accelerated Test Program [12], fatigue curves of different survival ratio from the test gears have been drawn and fatigue limit was acquired, as shown in Figure 1. The P$\mathrm{S}-\mathrm{N}$ curve indicated that the fatigue life and the increment of fatigue lives of nitrided+TiN coated samples were higher than those of the nitrided samples with the descending of stress levels. It was obvious that $\mathrm{TiN}$ coating could provide the subsurface protection and that properties of high cycle fatigue of nitrided samples could be improved by deposition of TiN. The contact fatigue strength of nitrided+TiN $32 \mathrm{Cr} 2 \mathrm{MoV}$ is $284 \mathrm{MPa}$ higher than that of nitrided $32 \mathrm{Cr} 2 \mathrm{MoV}$.

Figure 2 was the photograph of gear surface before gear rig contact test at contact stress $1235 \mathrm{Mpa}$. Both tooth faces with different surface treatment showed the uniform state without the scratches and defects.

After long time running test, there was significant comparison between the two kinds of tooth faces, which was demonstrated by Figure 3. It could be seen that the fatigue load obviously damaged the nitrided gears surfaces, and base metal is exposed with deep scratches, grooves, and spallings on tooth surface. As a distinction, nitrided+TiN coated gears were in good conditions relatively with less Horizontal grooves than the nitrided gears, few scratches and grooves were observed on nitrided+TiN coated driven gears, but it could be found that TiN coatings of driving gears on the edge of meshed zone were peeling off. There were some indentations on the nitrided+TiN coated driven gears but meshing zone kept original color and luster without the TiN coating peeling off. Marco-observation of tooth surface showed that TiN coating could increase the wear-resistance and resistance to contact fatigue.

The results of gears surfaces magnified 50 times were shown in Figure 4. Long time running caused serious fatigue wear on nitrided gear surface which emerged in forms of pitting and grooves. However, few pitting were observed on the nitrided $+\mathrm{TiN}$ coated gears, and wear of gear surface was too slight to exhaust the TiN coatings. According the gear status without TiN peeling off in Figure 4(d), The circle concave should not be pittings, which revealed that wear of TiN was uniform during the gear test.

The area of pitch line and edge of meshed zone of nitrided gears were investigated by SEM, as shown in Figure 5. All of the gears at the pitch line have the serious superficial injury, whose characteristics were also the fine pits and scratches with direction along the flank profiles (Figures 5(a) and $5(\mathrm{c})$ ), while on the edge of the meshing zone there were obviously large areas of peeling off (Figures 5(b) and 5(d)). The SEM micrograph and EDS results of nitrided+TiN gears are shown in Figure 6. The peeling off of TiN coated gears was less than that of nitrided gears, and TiN coatings on pitch line still existed and were covered on the tooth surface. However substrate exposed on the edge of meshed zone, which revealed that TiN coatings have peeling off. an explanation for this phenomenon was contact interference 
TABLE 4: Contact fatigue life of gears under different contact stress levels.

\begin{tabular}{lcccccccccc}
\hline \multirow{2}{*}{ Contact stress $\sigma / \mathrm{MPa}$} & \multicolumn{1}{c}{ Nitreded and TiN coated 32Cr2MoV } & \multicolumn{4}{c}{ Nitrided 32Cr2MoV } \\
\hline 2500 & 1.45 & 1.74 & 9.56 & 1.51 & 1.17 & 1.23 & 1.34 & 1.01 & 1.31 & 1.06 \\
2200 & 4.94 & 4.66 & 5.44 & 5.18 & 4.65 & 3.88 & 3.31 & 3.97 & 3.92 & 3.10 \\
2000 & 13.85 & 11.46 & 16.01 & 15.72 & 14.22 & 6.92 & 5.77 & 7.51 & 7.23 & 7.04 \\
1800 & 49.75 & 53.85 & 50.72 & 47.86 & 43.75 & 19.91 & 22.63 & 21.73 & 17.86 & 16.40 \\
\hline
\end{tabular}

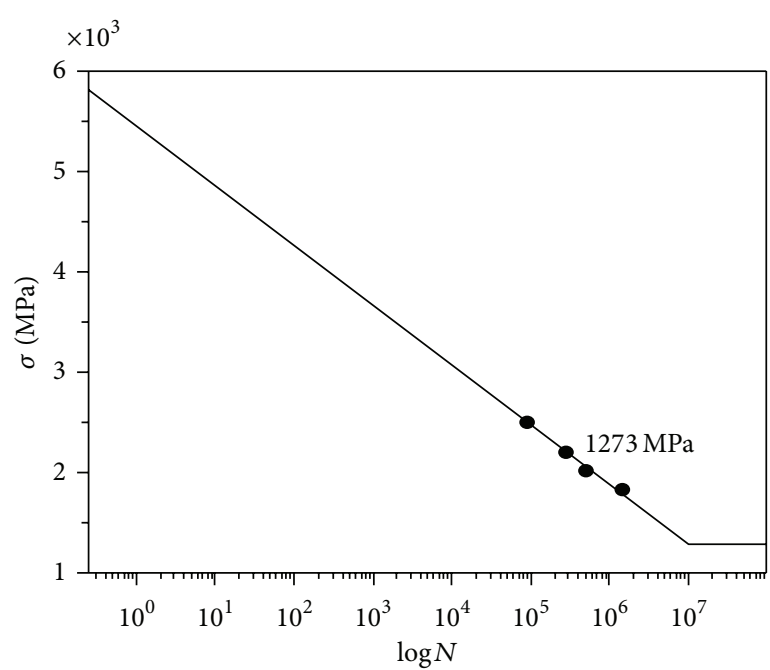

(a) Nitrided $32 \mathrm{Cr} 2 \mathrm{MoV}$

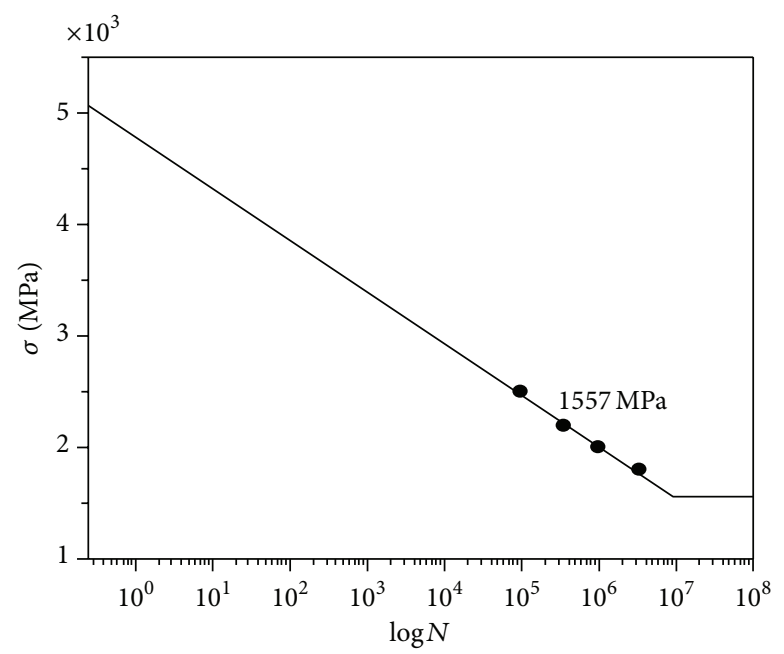

(b) Nitrided+TiN coated $32 \mathrm{Cr} 2 \mathrm{MoV}$

FIGURE 1: 99\% survival probability P-S-N curves.

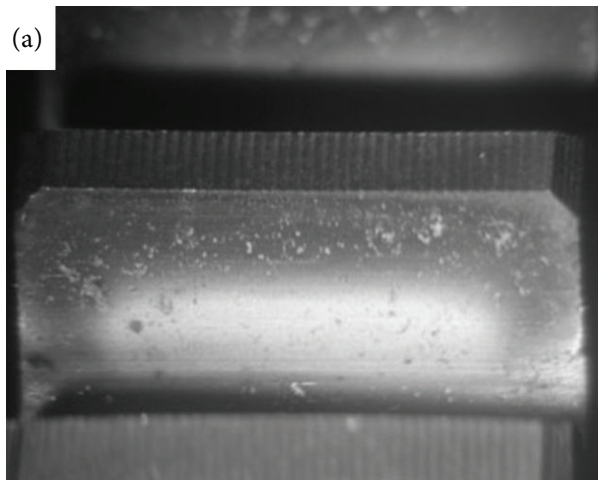

(a) Nitrided+TiN coated 32Cr2MoV

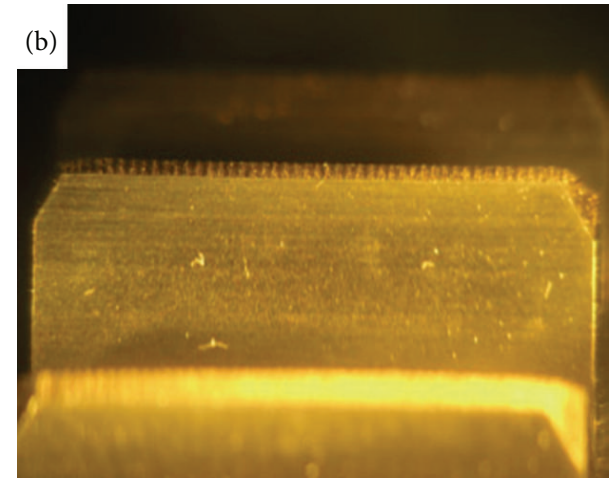

(b) Nitrided $32 \mathrm{Cr} 2 \mathrm{MoV}$

FIGURE 2: Tooth surface before gear rig contact test.

of gear shape between driven gears and drive gears $[8,13]$. Furthermore, the residual TiN coatings of all nitrided+TiN gears maintained a uniform state and color, without the wear scar and plowing grooves along the tooth profile, which sharply contrasted with the nitrided gears. The EDS results of coated gears were consistent with previous analysis. Normally, the element Fe could not be detected by EDS after TiN coatings have been deposited onto surface, which misfits the result of Figure 6 and demonstrates that wear of TiN coating has occurred during the gear running. The content of $\mathrm{Ti}$ and $\mathrm{Fe}$ in the different area revealed that wear of $\mathrm{TiN}$ on the edge of meshed zone was more severe than that on the pitch line zone. After running test some round spots and strip pits, the size of which was larger than that of the liquid-drop spots within $10 \mu \mathrm{m}$ found in the TiN surface by different PVD technology were observed on the TiN coated driven gears (Figures 3(d) and 4(d)). However, morphology of spots and strip pits was quite different from the warp or bulge of film and similar to the indentation, showing that the TiN coating has good toughness and deformation capacity. The indentation illustrated that the driven gear surface was deformed during the repeated sliding and rolling, and 


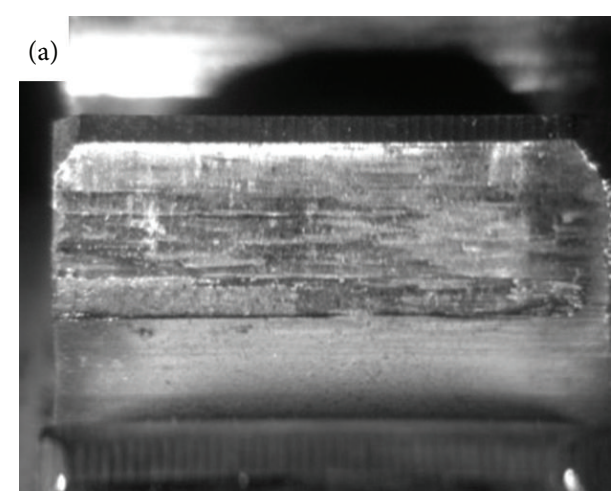

(a) Nitrided driving gears

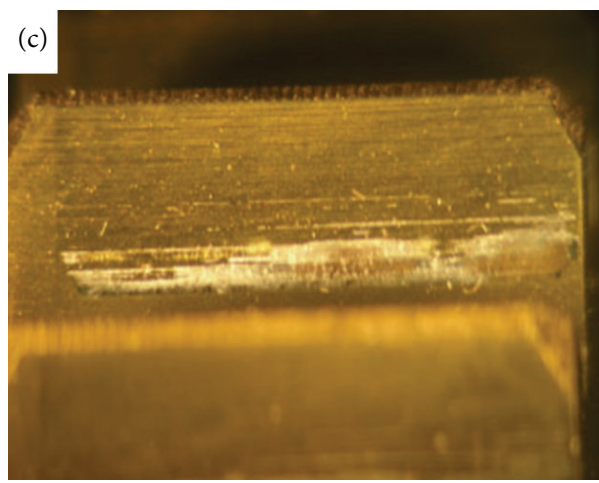

(c) Nitrided $+\mathrm{TiN}$ coated driving gears

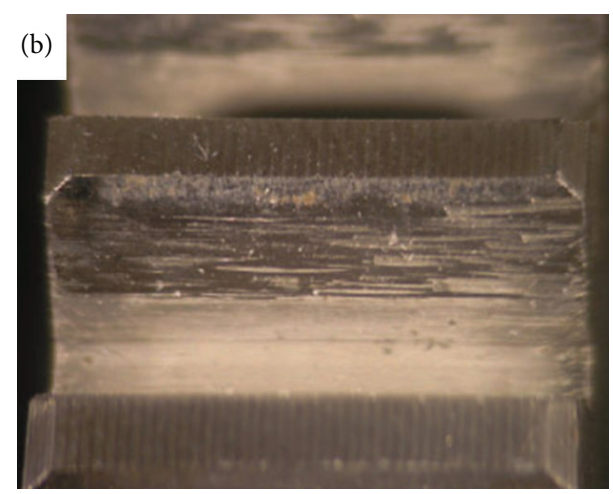

(b) Nitrided driven gears

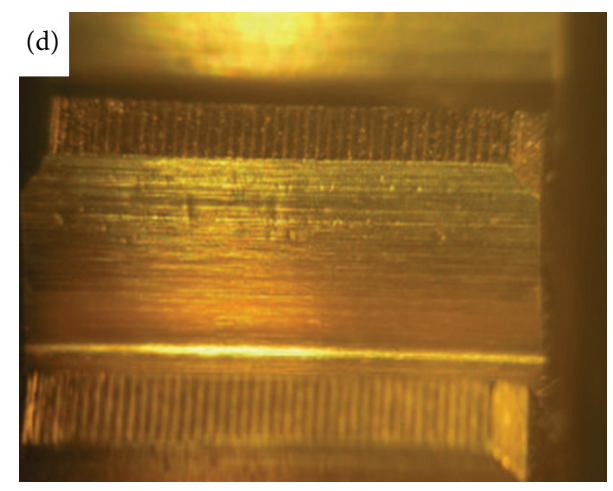

(d) Nitrided+TiN coated driven gears

FIgURE 3: The macrophotograph of tooth surface after running test.

the deformed material will rapture if the accumulated strain exceeds the critical value of plastic strain [14]. The failure characteristic of TiN coated gears was consistent with contact fatigue of traditional hardened gears, but TiN could improve the contact fatigue performance.

The observation of nitrided gears is consistent with gear failure rules: pittings usually occur on the site near tooth root and below the pitch line, and it is easier for generating pittings on the driving gears than driven gears; additionally heavy load may cause spalling $[15,16]$. Compared with the severe tooth damage of all nitrided gears, the TiN coated gears show an excellent resistance of pitting and spalling. TiN coatings within thickness $3 \mu \mathrm{m}$ still remain on the most of gear surface, which demonstrated wear of TiN coated gears is slighter. On the basis of the contact fatigue model, main failure type of hardened gears is pitting owing to its shallower nitride case and important role of surface cracks. Micro cracks caused by surface machining and repeated plastic deformation interact with lubricant and result in nucleation and propagation of fatigue cracks $[8,14,15]$. Deposition with TiN coating wrapped up the gear tooth so that the gear surface no longer contacts with lubricant and prevents the cracks initiation; furthermore, brittle TiN coating combined with hard case may weaken the surface plastic deformation, prolonging the contact fatigue life of gears. After the TiN coating wore out, the conditions of nitrided+TiN gears are the same as nitrided gears, and pitting process is similar to nitrided gears.
The changes in surface roughness also reflected the wear of gears, as shown in Figure 7. The surface roughness of nitrided gears increased to about $\Delta \mathrm{Ra} 0.6 \sim 0.7 \mu \mathrm{m}$, which indicated that pitting destroyed the smoothness of nitrided gears. Reversely, surface roughness $\mathrm{Ra}$ of TiN coated gears decreased, making tooth surface smoother, and helping reduce the friction and wear, and improving and inhibiting pitting of gears.

\section{Conclusions}

From the previous discussion, the conclusion can be summarized as follows.

(1) The deposition on gears by hard coating TiN can provide subsurface protection and improve the contact fatigue life. The contact fatigue strength of nitrided+TiN coated $32 \mathrm{Cr} 2 \mathrm{MoV}$ is $1557 \mathrm{Mpa}$ at survival probability of $99 \%$, and it is $284 \mathrm{MPa}$ higher than that of nitrided $32 \mathrm{Cr} 2 \mathrm{MoV}$.

(2) Due to the protection of TiN coatings with good toughness and deformation capacity, feature of gear surface fatigue exhibit indentation instead of pittings, which is different from the pittings and liquid-drop spots within $10 \mu \mathrm{m}$ found in the TiN deposition. The meshing zone of coated TiN gear face keeps well basically without pittings and wear grooves, which is opposite to nitrided gears with pittings and 


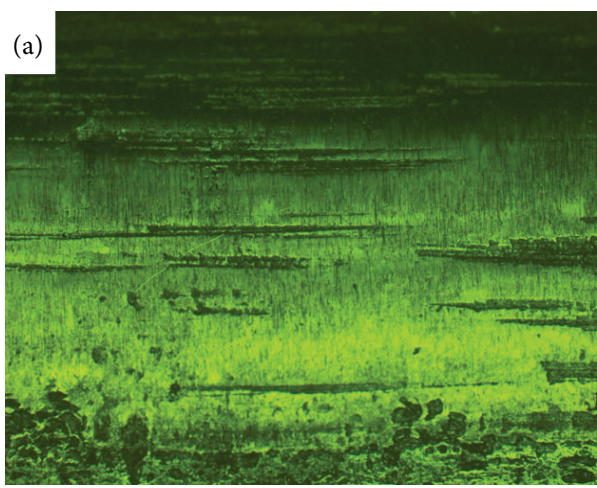

(a) Nitrided driving gears

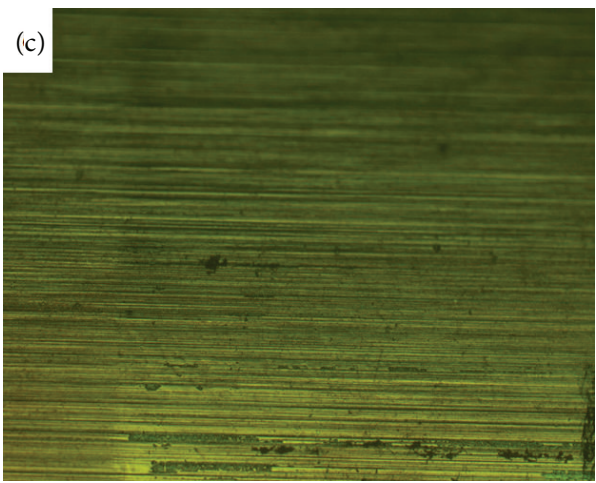

(c) Nitrided+TiN coated driving gears

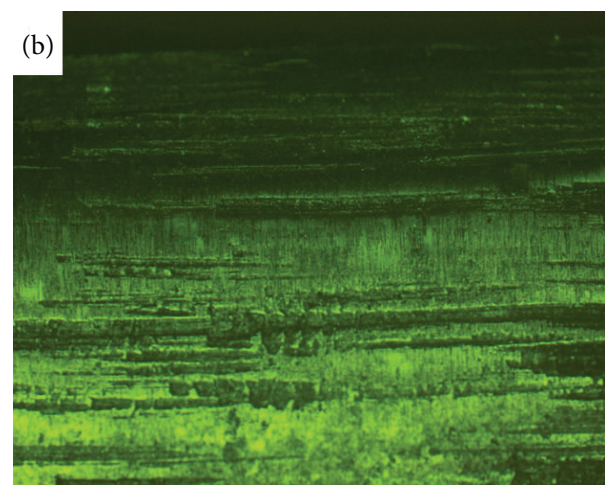

(b) Nitrided driven gears

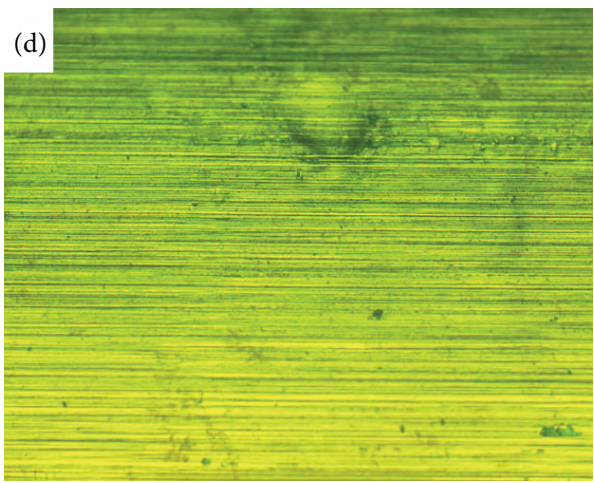

(d) Nitrided+TiN coated driven gears

Figure 4: The photograph of tooth surface after running test magnified 50 times.

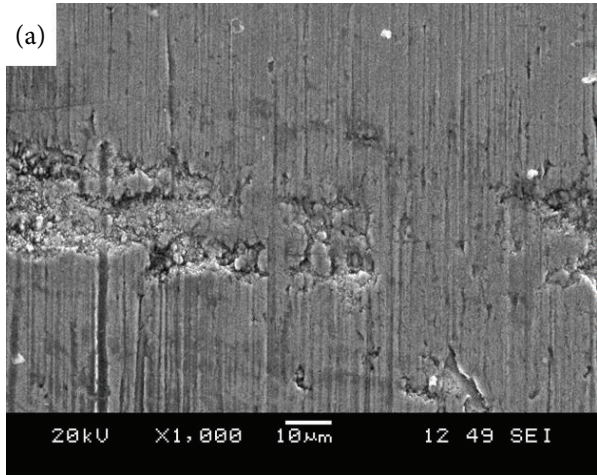

(a) Pitch line of driving gear

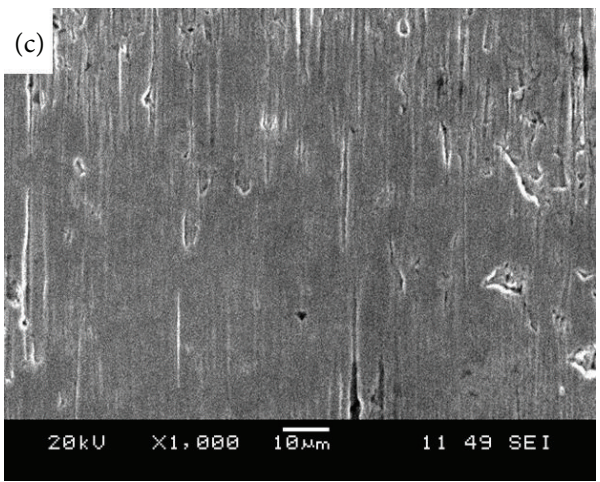

(c) Pitch line of driven gear

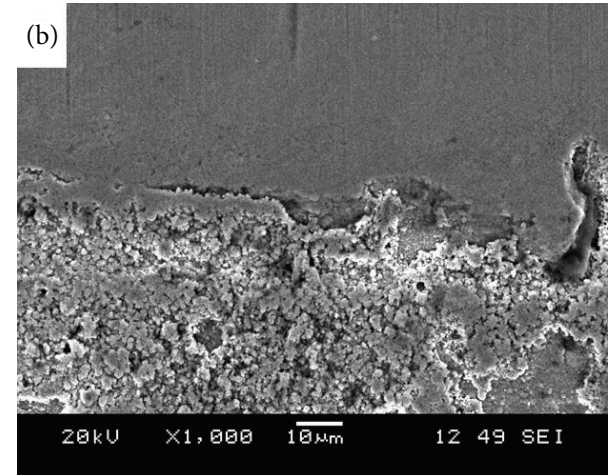

(b) Edge of meshed zone of driving gear

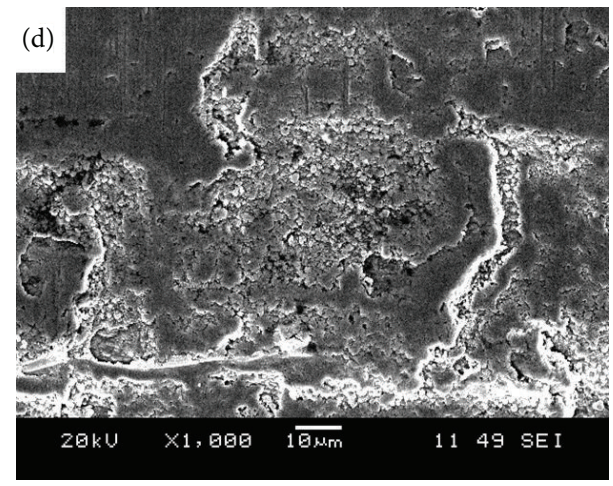

(d) Edge of meshed zone of driven gear

FIGURE 5: The SEM micrograph of nitrided gears after running test. 

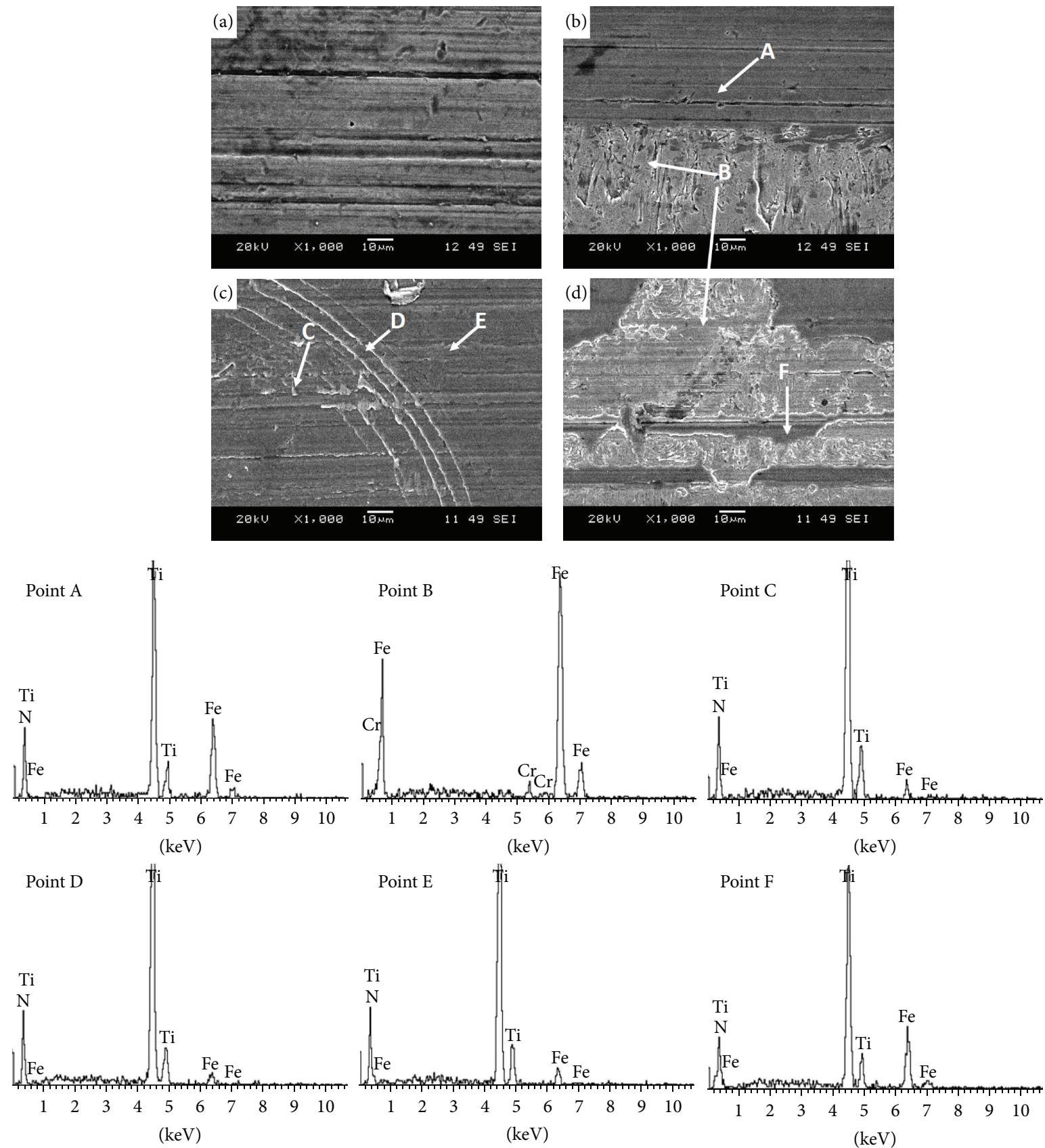

Full scale 135 cts cursor: 0.000

Full scale 135 cts cursor: 0.000

Full scale 135 cts cursor: 0.000

\begin{tabular}{ccccccc}
\hline \multirow{2}{*}{ Element } & \multicolumn{7}{c}{ Weight (\%) } \\
\cline { 2 - 7 } & $\mathrm{A}$ & $\mathrm{B}$ & $\mathrm{C}$ & $\mathrm{D}$ & $\mathrm{E}$ & $\mathrm{F}$ \\
\hline $\mathrm{N} \mathrm{K}$ & 25.42 & - & 27.07 & 22.94 & 22.61 & 18.57 \\
Ti K & 44.65 & - & 66.32 & 73.22 & 70.78 & 54.58 \\
Fe K & 29.93 & 97.25 & 6.61 & 3.84 & 6.62 & 26.68 \\
Cr K & - & 2.75 & - & - & - & - \\
\hline
\end{tabular}

FIGURE 6: The SEM micrograph of nitrided+TiN gears after running test; (a) pitch line of driving gear, (b) edge of meshed zone of driving gear, (c) pitch line of driven gear, and (d) edge of meshed zone of driven gear. 


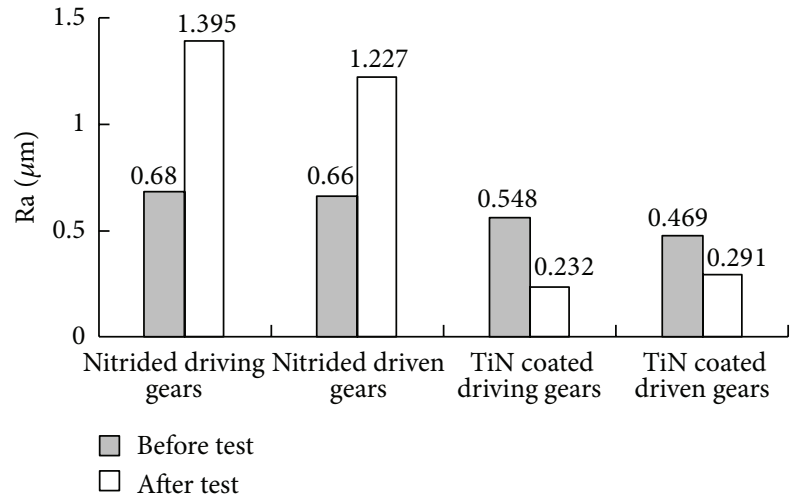

FIGURE 7: Surface roughness of gears.

peeling off. Even on the edge of the meshing zone TiN coatings have been worn out, the gear face kept well without pittings. The surface of the TiN coating is dense and smooth with lower surface roughness, and it wraps up the gear tooth so that the gear surface no longer contacts with lubricant and prevents the cracks initiation. During the running test, surface roughness of TiN coated gears decreased, making tooth surface smoother and helping reduce the friction and wear, improving contact fatigue properties.

\section{Acknowledgments}

This work has been supported by National Natural Science Foundation of China (no. 51275548), Chongqing Science and Technology Commission (no. cstc2012jjB70002), and International Cooperation Special Project in Science and Technology of China (2013DFA70730). Authors are grateful to State Key Laboratory of Mechanical Transmission in Chongqing University for providing the specimens and gear experimental equipment.

\section{References}

[1] R. C. Martins, P. S. Moura, and J. O. Seabra, "MoS 2 /Ti lowfriction coating for gears," Tribology International, vol. 39, no. 12, pp. 1686-1697, 2006.

[2] M. Kalin and J. Vižintin, "The tribological performance of DLC-coated gears lubricated with biodegradable oil in various pinion/gear material combinations," Wear, vol. 259, no. 7-12, pp. 1270-1280, 2005.

[3] J. C. Jiang, W. J. Meng, A. G. Evans, and C. V. Cooper, "Structure and mechanics of W-DLC coated spur gears," Surface and Coatings Technology, vol. 176, no. 1, pp. 50-56, 2003.

[4] C. Mercer, A. G. Evans, N. Yao, S. Allameh, and C. V. Cooper, "Material removal on lubricated steel gears with W-DLC-coated surfaces," Surface and Coatings Technology, vol. 173, no. 2-3, pp. 122-129, 2003.

[5] S. Baragetti, "Fatigue resistance of steel and titanium PVD coated spur gears," International Journal of Fatigue, vol. 29, no. 9-11, pp. 1893-1903, 2007.
[6] J. Luo, H. Dong, and T. Bell, "Model-based contact fatigue design of surface engineered titanium gears," Computational Materials Science, vol. 35, no. 4, pp. 447-457, 2006.

[7] Q. Wenfu, C. Xingjin, L. Long et al., "Surface treatment and coating technologies on gears," Journal of Chongqing University, vol. 2, pp. 1-4, 2005 (Chinese).

[8] M. Fujii, M. Seki, and A. Yoshida, "Surface durability of WC/Ccoated case-hardened steel gear," Journal of Mechanical Science and Technology, vol. 24, no. 1, pp. 103-106, 2010.

[9] L. Lu, F. Xu, T. Jiang, Q. Zhang, and S. Lyu, "Characteristic evaluation of friction and wear in the $\mathrm{C}-\mathrm{N}$ and TiN coated gear," International Journal of Precision Engineering and Manufacturing, vol. 11, no. 1, pp. 107-111, 2010.

[10] N. Dingremont, E. Bergmann, and P. Collignon, "Application of duplex coatings for metal injection moulding," Surface and Coatings Technology, vol. 72, no. 3, pp. 157-162, 1995.

[11] S. Ma, Y. Li, and K. Xu, "The composite of nitrided steel of $\mathrm{H} 13$ and TiN coatings by plasma duplex treatment and the effect of pre-nitriding," Surface and Coatings Technology, vol. 137, no. 2-3, pp. 116-121, 2001.

[12] M. B. Feng and Y. L. Chen, "Fixed emitting point methodan accelerated test program to determine fatigue limit of automotive components," SAE Technical Paper 2004-01-1646, SAE International, 2004.

[13] M. Murakawa, T. Komori, S. Takeuchi, and K. Miyoshi, "Performance of a rotating gear pair coated with an amorphous carbon film under a loss-of-lubrication condition," Surface and Coatings Technology, vol. 120-121, pp. 646-652, 1999.

[14] G. W. Stachowiak, Engineering Tribology, Elsevier, 3rd edition, 2006.

[15] J. W. Blake and H. S. Cheng, "A surface pitting life model for spur gears," Tribology, vol. 113, pp. 712-718, 1991.

[16] T. E. Tallian, "Simplified contact fatigue life prediction model," Journal of Tribology, vol. 2, pp. 207-220, 1992. 

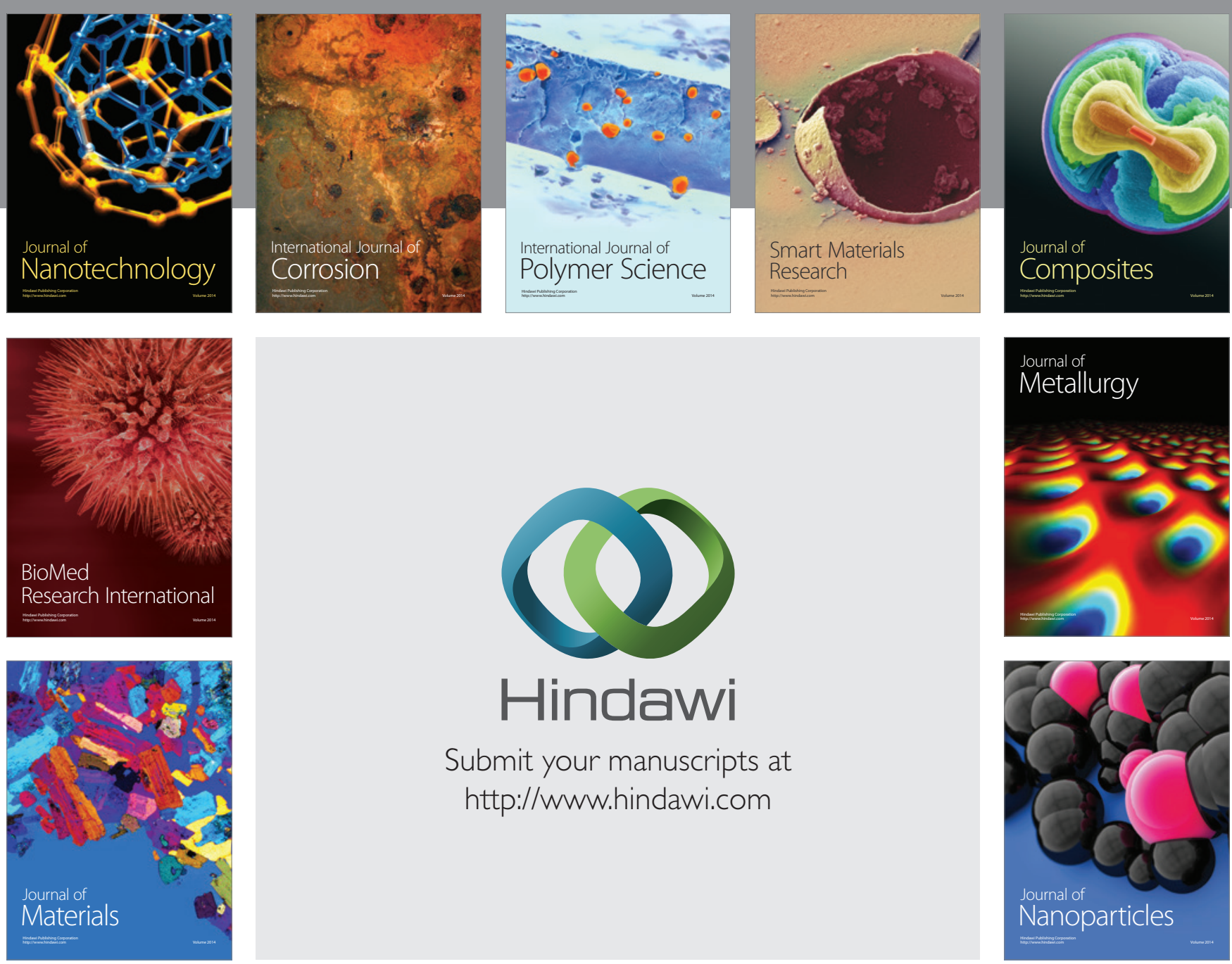

Submit your manuscripts at http://www.hindawi.com
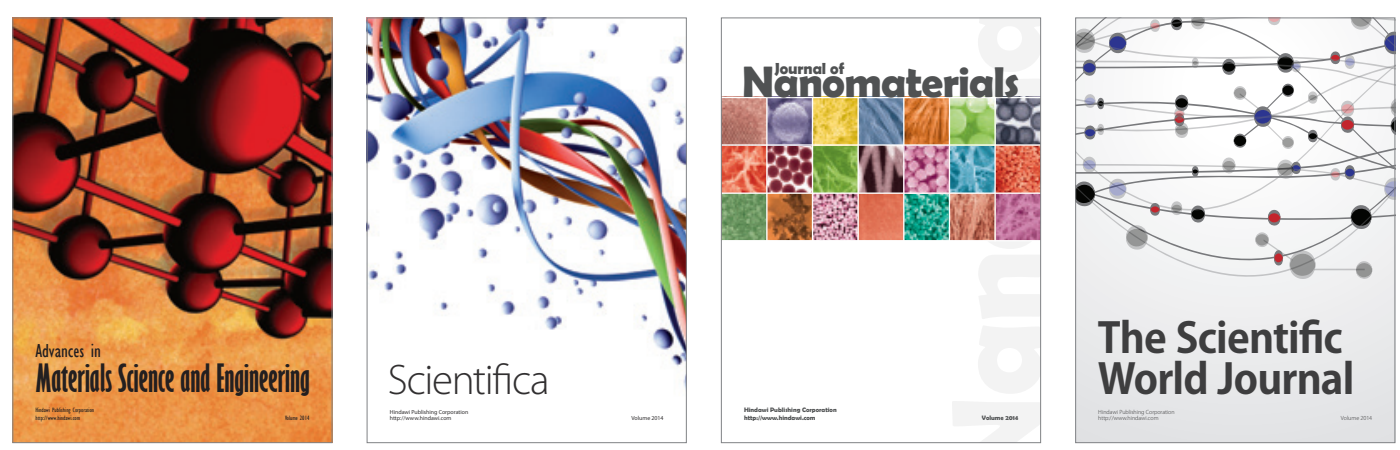

\section{The Scientific World Journal}
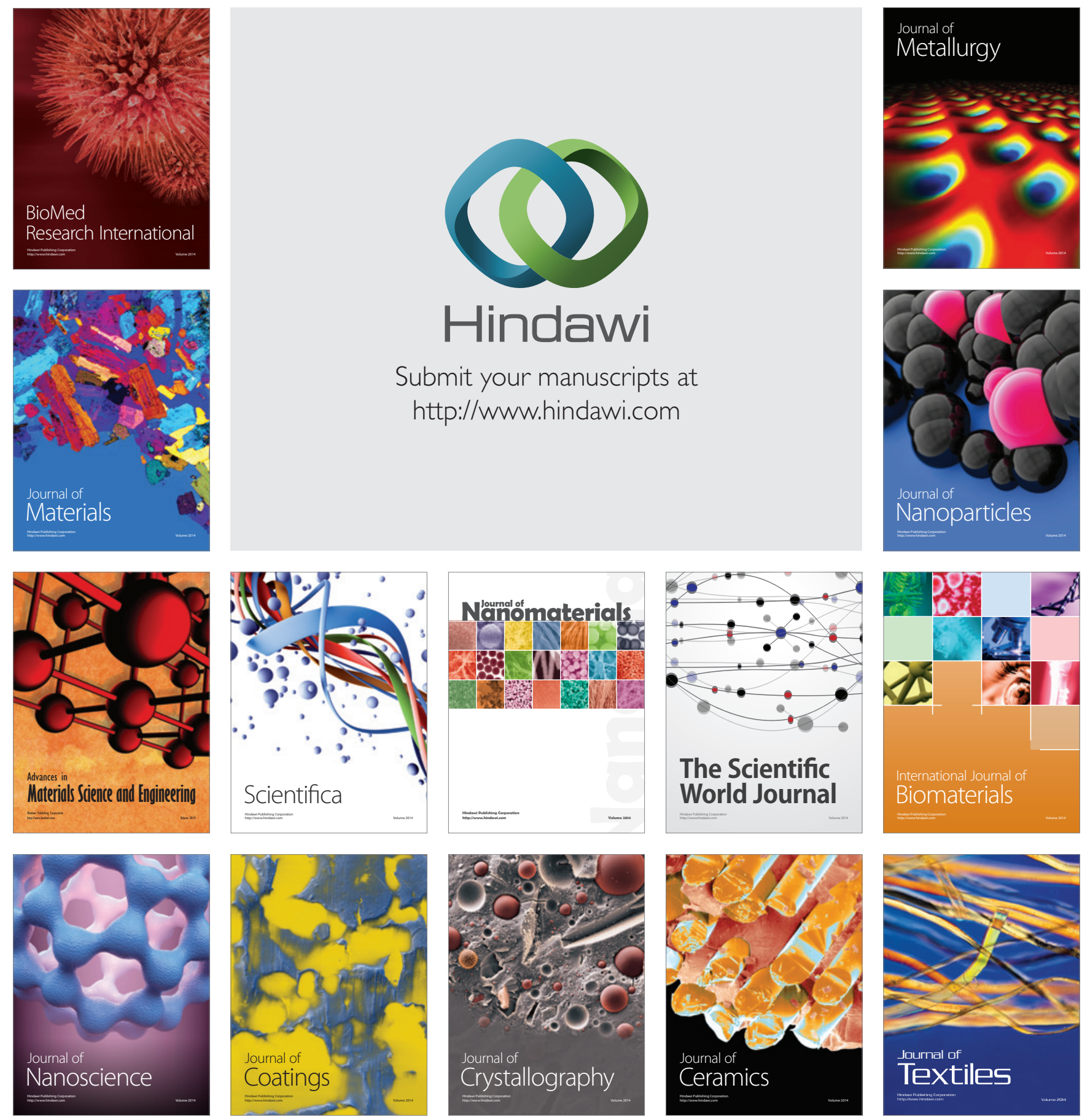